\title{
OPTIMALISASI PENGELOLAAN USAHA KECIL MENENGAH (UKM) KERUPUK DOROKDOK DESA CIBINGBIN KECAMATAN CIBINGBIN, KABUPATEN KUNINGAN
}

\author{
Dadang Suhendar ${ }^{1}$ dan Dadang Suhardi ${ }^{2}$ \\ ${ }^{1}$ Program Studi Akuntansi, Fakultas Ekonomi, Universitas Kuningan \\ ${ }^{2}$ Program Studi Manajemen, Fakultas Ekonomi, Universitas Kuningan \\ E-mail : dadang.suhardi@uniku.ac.id
}

\begin{abstract}
PkM activity was implemented in Cibingbin village, Cibingbin district, Kuningan regency with the target the entrepreneurs who involve with UKM belonging to kerupuk Dorokdok UKM. The activity implementation method consisted of three steps. The first step was preparation covering pre-survey, team-work, production and proposal dispatch, team coordination and partner and also tool preparation as well as exercising materials. The second step was the step to implement the program such as giving socialization, tutorial activity and discussion. Socialization was done through material description and discussion. The third step was evaluation and report. Evaluation was done by comparing partner condition before and after program implemented through interview method and observation. The proposed material in socialization derived from the importance of making financial report or simple accounting for entrepreneurs in UKM. The outside outcome after the socialization was implemented were : The first : The socialization in introducing how to make financial report or simple accounting for UKM has fulfilled the targeted outcome through the improvement on how to make financial report or simple accounting. It was seen after socialization that the members could describe the aim of the financial report or simple accounting in business activity. The second : the existed tutorial activity led UKM to understand better on how to make simple financial report good and clear.
\end{abstract}

Keywords : socialization, tutorial activity, accounting

\begin{abstract}
Abstrak
Kegiataan PkM dilaksanakan di Desa Cibingbin Kecamatan Cibingbin Kabupaten Kuningan dengan target pelaku usaha UKM yang merupakan UKM Kerupuk Dorokdok. Metode pelaksanaan kegiatan terdiri dari tiga tahap. Pertama tahap persiapan meliputi pra survey, pembentukan tim, pembuatan dan pengajuan proposal, koordinasi tim dan mitra serta persiapan peralatan dan bahan-bahan pelatihan. Tahap kedua yaitu tahap pelaksanaan program berupa ceramah atau sosialisasi, kegiatan tutorial, dan diskusi. Sosialisasi dilakukan melalui penyuluhan (pemaparan materi) dan diskusi. Tahap ketiga yaitu tahap evaluasi dan pelaporan. Evaluasi dilakukan dengan membandingkan kondisi mitra sebelum dan sesudah dilaksanakannya program dengan metode wawancara dan observasi. Materi yang disampaikan dalam sosialisasi berupa pentingnya pembuatan laporan keuangan atau pembukuan sederhana untuk pelaku UKM. Hasil dan luaran kegiatan setelah dilaksanakan sosialisasi yaitu pertama, sosialisasi pengenalan pembuatan laporan keuangan atau pembukuan yang sederhana untuk UKM telah memenuhi luaran yang ditargetkan, yaitu terjadi peningkatan pemahaman mengenai pembuatan laporan keuangan atau pembukuan sederhana sehingga settelah sosialisasi diberikan maka peserta dapat menjelaskan tujuan dari pembuatan laporan keuangan atau pembukuan dalam kegiatan usaha. Kedua, Kegiatan tutorial yang dilakukan membuat UKM lebih memahami bagaimana membuat laporan keuangan yang sederhana terlihat baik dan jelas.
\end{abstract}

Kata Kunci : Sosialisasi,,Kegiatan Tutorial, Pembukuan

\section{PENDAHULUAN}

UKM adalah suatu bentuk usaha mikro, kecil menengah ang ada di kalangan masyarakat dimana usaha ini didirikan berdasarkan inisiatif seseorang. Sebagian besar opini yang ada dikalangan masyarakat menganggap bahwa UKM hanya dapat menguntungkan pihak-pihak tertentu saja. Padahal UKM juga dapat berperan membantu pemerintah dalam mengurangi tingkat pengangguran yang ada di Indonesia. UKM di Indonesia mampu menyerap banyak tenaga kerja Indonesia yang masih belum 
mempunyai pekerjaan atau mengganggur. Selain itu, UKM telah berkontribusi besar dalam meningkatkan pendapatan daerah maupun pendapatan negara Indonesia. UKM dapat memanfaatkan berbagai Sumber Daya Alam yang berpotensial di daerahnyayang belum diolah secara komersial sehigga UKM dapat berkontribusi dan membantu mengolah Sumber Daya Alam yang ada di daerah dimana UKM itu berada. Hal ini dapat berkontribusi besar terhadap peningkatan pendapatan daerah maupun pendapatan negara Indonesia.

Pembukuan bukan dikhususkan hanya digunakan oleh perusahaan yang telah besar namanya atau telah maju saja. Akan tetapi, pembukuan juga wajib digunakan oleh usahaberskala kecil dan menengah atau bisa disebut dengan UKM. Pembukuan mempunyai peranan yang sangat penting untuk keberlangsungan hidup UKM, sebenarnya UKM tidak memerlukan pembukuan yang dianggap sulit, UKM dapat atau bisa membuat dan menggunakan pembukuan sederhana. Pembukuan juga dianggap mempunyai peran yang sangat penting yaitu pembukukan digunakan untuk mengetahui berapa keuntungan dan kerugian yang kita peroleh.Salah satu permasalahan yang dihadap oleh Ukm adalah permasalahan di bidang keuangan. Permasalahan di bidang keuangan menjadi salah satu masalah yang paling krusial yang sering terjadi pada UKM di Indonesia. Hal ini disebabkan oleh pemilik UKM yang tidak memiliki kemampuan dalam mengelola keuangan sehingga banyak UKM di Indonesia yang tidak memiliki pembukuan yang rapih dan jelas. Meskipun pembukuan dapat dibuat dengan sangat sederhana, asal pembukuan tersebut rapih dan jelas maka pembukuan itu akan sangat membantu kita dalam mengatur keuangan UKM.

Pembukuan yang sederhana wajib kita miliki sebagai pelaku UKM. Namun pembukuan ini sangat penting bagi kita agar bisa melihat kondisi keuangan yang terjadi pada bisnis milik kita. Tanpa adanya pembukuan , maka kita tidak mengetahui sudah sejauhmana perkembangan bisnis kita.Usaha Kecil Menengah (UKM) memerlukan perhatian yang khusus dan UKM dalam perkembangannya harus didukung oleh informasi yang akurat sehingga dapat terjadi link bisnis yang terarah antara pelaku usaha kecil dan menengah dengan elemen daya saing usaha, yaitu jaringan pasar. Usaha Kecil Menengah (UKM) mempunyai peranan yang strategis dalam pembangunan nasional karena selain berperan dalam pertumbuhan ekonomi dan penyerapan tenaga kerja, keberadaan UKM di kalangan masyarakat juga dapat memberikan andil yang besar dalam pendistribusian hasil - hasil pembangunan. Semenjak krisis ekonomi menimpa negara Indonesia beberapa waktu belakangan ini, sektor usaha kecil dan menengah (UKM) justru terbukti lebih tangguh dalam menghadapi krisis tersebut dibandingkan dengan usaha-usaha lain yang lebih besar. Sehingga dapat disimpulkan bahwa pengembangan UKM kedepannya diperlukan perhatian yang besar baik dari pemerintah ataupun masyarakat agar UKM dapat berkembang lebih kompetitif dibandingkan dengan pelaku ekonomi lainnya.

Pemerintah merupakan salah satu pihak yang memiliki kekuasaan untuk membuat suatu kebijakan yang diharapkan mampu mendukung penuh pertumbuhan dan perkembangan UKM dengan meningkatkan perannya untuk memberdayakan UKM 
disamping mengembangkan kemitraan usaha yang saling menguntungkan antara pengusaha besar dengan pengusaha kecil. Selain itu, peningkatan kualitas sumber daya manusia yang dimiliki UKM adalah salah satu pekerjaan rumah yang harus dilakukan agar kedepannya UKM yang ada bisa bersaing da memiliki daya saing di era globalisasi. Hal ini dikarenakan UKM sering terlilit hambatan dalam perluasan jaringan usaha yang sangat terbatas dan kemampuan penetrasi pasar yang rendah, oleh karena itu produk yang dihasilkan oleh UKMjumlahnya sangat terbatas dan hal itu menyebabkan kesulitan menembus pasar nasional apalagi ke pasar internasional.

Pada umumnya permasalahan yang dihadapi UKM adalah permodalan yang dimiliki UKM yang masih mengandalkan pada modal dari pemilik UKM yang jumlahnya sangat terbatas sehingga produksi kurang lancar. Usaha Kecil Menengah tumbuh secara tradisional dan turun temurun, keterbatasan SDM usaha kecil baik dari segi pendidikan formal maupun pengetahuan dan keterampilannya sangat berpengaruh terhadap manajemen pengelolaan usahanya dan relatif sulit untuk mengetahui perkembangan teknologi baru untuk meningkatkan daya saing produk yang dihasilkan sehingga usaha tersebut kurang optimal. Kurangnya informasi yang berhubungan dengan kemajuan ilmu pengetahuan dan teknologi, menyebabkan sarana dan prasarana yang mereka miliki juga tidak cepat berkembang dan kurang mendukung kemajuan usahanya sebagaimana yang diharapkan. Dan masih ada UKM yang belum dilengkapi dengan legalitas yang harus dimiliki setiap UKM.Oleh karena itu, kami melakukan pengabdian pada masyarakat pada salah satu UKM kerupuk Dorokdok di Desa Cibingbin Kecamatan Cibingbin.

Pemasalahan Mitra, Berdasarkan analis situasi yang telah dipaparkan, dapat disimpulkan bahwa permasalahan mitra adalah ketidakmampuan dalam mengelola keuangan sehingga banyak UKM yang tidak memiliki pembukuan yang rapih dan jelas. Solusi Permasalahan, Adapun solusi yang ditawarkan dalam program PkM ini yang disesuaikan dengan pemasalahan mitra adalah melakukan sosialisasi mengenai pencatatan keuangan secara sederhana dan mudah dimengerti untuk UKM yang ada di Desa Cibingbin Kecamatan Cibingbin Kabupaten Kuningan Target Luaran, Target luaran yang dihasilkan dari kegiatan Pengabdian Kepada Masyarakat (PkM) Universitas Kuningan ini diharapkan Usaha Kecil Menengah (UKM) Kerupuk Dorokdok dan masyarakat Desa Cibingbin Kecamatan Cibingbin Kabupaten Kuningan memahami dan bisa menciptakan, mengimplementasikan Pencatatan Keuangan Untuk Usaha Kecil secara maksimal.

Manfaat dan Dampak Sosial, Adapun manfaat dan dampak sosial yang didapat dari kegiatan PKM ini adalah sebagai berikut :

1. UKM dapat mengetahui jumlah keuntungan dan kerugian

Dengan adanya catatan keuangan maka UKM bisa mengetahui berapa jumlah kerugian dan keuntungan yang UKM tersebut dapatkan setiap harinya. Dengan begitu UKM juga bisa mengetahui jumlah modal yang sudah terpakai, dan modal yang belum digunakan, termasuk berapa jumlah utang yang UKM tersebut 
miliki.Sehingga semua tercatat dengan rapih, UKM pun bisa mudah mengetahui untung yang UKM tersebut peroleh dalam satu bulan, dua bulan, tiga bulan dan seterusnya dalam satu tahun. UKM juga bisa melihat daftar keuntungan yang UKM peroleh dari catatan-catatan yang telah UKM buat tersebut.

2. Pembukuan yang dilakukan oleh UKM dapat dijadikan panduan atau pedoman untuk membuat rencana yang akan dilakukan di masa yang akan datang

3. UKM dapat mengetahui posisi keuangan

Setiap usaha yang dijalankan dengan modal, maka diperlukan untuk mengetahui bagaimana cara melihat posisi keuangan bisnis yang dijalankan tersebut. Salah satu cara yang bisa dilakukan untuk mengetahui posisi keuangan pada UKM adalah dengan membuatkan catatan untuk mengetahui transaksi-transaksi yang terjadi dalam bisnis yang UKM tersebut kelola. Dengan menjalankan pencatatan akuntansi sederhana maka pemilik UKM dapat mengetahui, berapa uang kas yang UKM miliki, berapa utang yang UKM miliki, berapa nilai asset yang UKM miliki, berapa jumlah utang yang harus UKM bayarkan, dan sebagainya akan terlihat secara jelas.

4. Dengan adanya pencatatan keuangan yang dilakukan oleh UKM dapat memudahkan untuk melakukan peminjaman

\section{METODE PELAKSANAAN}

Ada beberapa metode pendekatan yang digunakan dalam pelaksanaan program pengaddian masyarakat yaitu, meliputi:

\section{Sosialisasi}

Program pengabdian kepada masyarakat dilaksanakan dalam bentuk sosialisasi kepada mitra pelaku usaha UKM Kerupuk Dorokdok di Desa Cibingbin Kecamatan Cibingbin. Sosialisasi tersebut berupa pemaparan materi kepada mitra terkait permasalahan yang dihadapi mitra yaitu pembuatan laporan keuangan atau pembukuan usaha. Materi yang disampaikan diharapkan dapat memberikan peningkatan pengetahuan dan pemahaman untuk selanjutnya dapat diterapkan oleh mitra dalam kegiatan usaha.

2. Kegiatan Tutorial

Setelah materi dipaparkan maka tim program PkM akan melakukan kegiatan tutorial dan praktikum yang akan diikuti oleh mitra yang bersangkutan.

3. Diskusi

Setelah materi selesai di paparkan, dilanjutkan dengan diskusi berupa tanya jawab antara pemateri dengan mitra. Diskusi dilakukan agar mitra lebih memahami materi yang telah disampaikan. Melalui diskusi, sosialisasi tidak hanya sekedar transfer knowledge saja melainkan dapat sharing pengalaman maupun permasalahan yang sedang dihadapi mitra. 


\section{HASIL DAN PEMBAHASAN}

Tahapan kegiatan program pengabdian kepada masyarakat PkM adalah sebagai berikut:

1. Tahap persiapan

a. Pra-Survei : Identifikasi permasalahan \& kebutuhan mitra (permasalahan spesifik yang dialami mitra).

b. Pembentukan Tim PkM : Pembentukan Tim disesuaikan dengan jenis kepakaran untuk menyelesaikan permasalahan mitra.

c. Pembuatan Proposal : Pembuatan proposal untuk menawarkan solusi permasalahan dan penye solusi bagi mitra.

d. Koordiasi Tim dan Mitra : Perencanaan pelaksanaan program secara konseptual, operasional dan job describtion dari Tim dan Mitra.

e. Persiapan Alat dan Bahan Pelatihan : Pembelian dan penyewaan alat serta pembuatan materi kegiatan.

2. Tahap pelaksanaan (Kegiatan dilaksanakan di lokasi mitra)

a. Sosialisasi Pentingnya Pencatatan laporan keuangan untuk UKM : Kegiatan dilaksanakan melalui pemaparan materi dan diskusi.

b. Sosialisasi materi UKM : Kegiatan dilaksanakan melalui pemaparan dan diskusi.

c. Praktek dan simulasi : Kegiatan dilaksanakan melalui pemaparan materi dan diskusi.

3. Evaluasi program : Dilakukan dengan membandingkan kondisi mitra sebelum dan sesudah pelaksanaan program. Indikator keberhasilan program dengan adanya perubahan positif dari mitra (perkembangan usaha) setelah pelaksaan program

4. Pelaporan : Penyusunan laporan dilakukan sebagai bentuk pertanggungjawaban atas pelaksanaan program untuk kemudian dilakukan publikasi

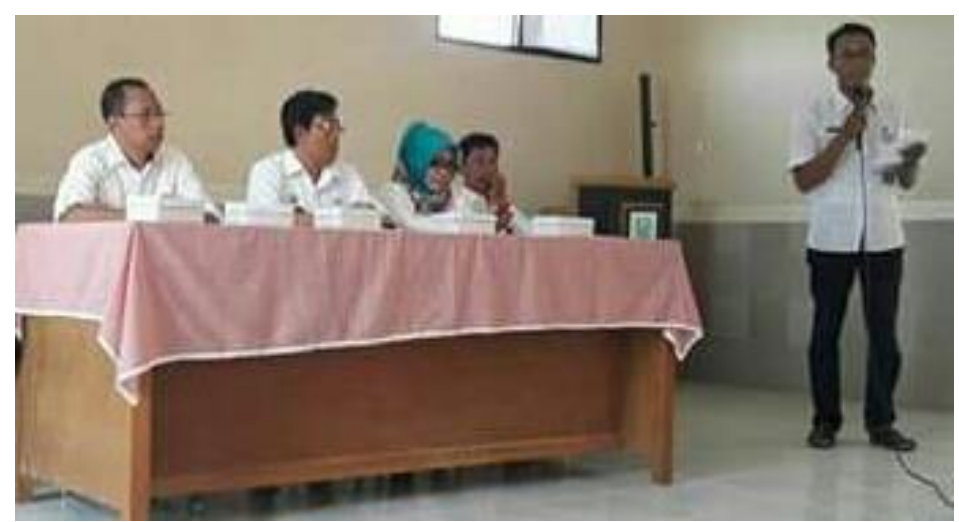

Gambar 1

Penyampaian Materi Mengenai

Pentingnya Pembukuan Sederhana Untuk UKM 


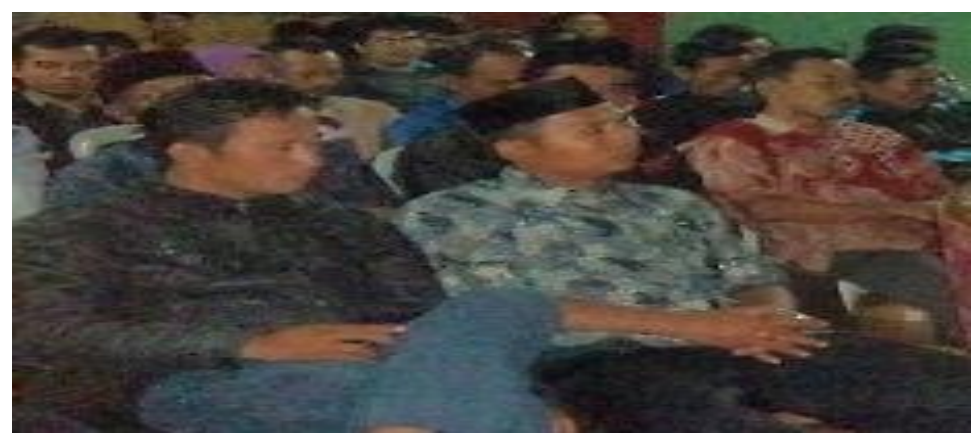

Gambar 2

Peserta Pelatihan dengan tema Optimalisasi Pengelolaan

Usaha Kecil Menengah (UKM) Kerupuk Dorokdok

Desa Cibingbin Kecamatan Cibingbin Kabupaten Kuningan

Tabel 1

Jadwal Kegiatan

\begin{tabular}{|c|c|c|}
\hline WAKTU & ACARA & PENANGGUNGJAWAB \\
\hline \multicolumn{3}{|c|}{ Kamis, 19 Juli 2018} \\
\hline $15.00-15.30$ & Persiapan & Tim PkM dan mitra \\
\hline $15.30-15.45$ & Pembukaan acara & $\begin{array}{l}\text { PerwakilanTim PkM } \\
\text { Perwakilan Desa }\end{array}$ \\
\hline $15.45-16.45$ & $\begin{array}{l}\text { Materi mengenai UKM } \\
\text { Diskusi/tanya jawab }\end{array}$ & Dadang Suhardi, SE,MM \\
\hline $16.45-17.00$ & Penutupan acara & $\begin{array}{l}\text { PerwakilanTim PkM } \\
\text { Perwakilan Desa }\end{array}$ \\
\hline \multicolumn{3}{|c|}{ Jumat, 20 Juli 2018} \\
\hline $15.00-15.30$ & Persiapan & Tim PkM dan mitra \\
\hline $15.30-15.45$ & Pembukaan acara & $\begin{array}{l}\text { PerwakilanTim PkM } \\
\text { Perwakilan Desa }\end{array}$ \\
\hline $15.45-16.45$ & $\begin{array}{l}\text { Materi mengenai pentingnya } \\
\text { pembukuan sederhana untuk UKM } \\
\text { Materi pembukuan sederhana sesi I } \\
\text { Diskusi/tanya jawab }\end{array}$ & $\begin{array}{l}\text { Dadang Suhendar, SE., } \\
\text { M.Si }\end{array}$ \\
\hline $16.45-17.00$ & Penutupan acara & $\begin{array}{l}\text { PerwakilanTimPkM } \\
\text { Perwakilan Desa }\end{array}$ \\
\hline \multicolumn{3}{|c|}{ Sabtu, 21 Juli 2018} \\
\hline 09.00-09.30 & Persiapan & Tim PkM dan mitra \\
\hline $09.30-09.45$ & Pembukaan acara & $\begin{array}{l}\text { PerwakilanTim PkM } \\
\text { Perwakilan Desa }\end{array}$ \\
\hline $09.45-10.45$ & $\begin{array}{l}\text { Materi mengenai pembukuan } \\
\text { sederhana sesi } 2 \\
\text { Diskusi/tanya jawab }\end{array}$ & $\begin{array}{l}\text { Dadang Suhendar, SE., } \\
\text { M.Si }\end{array}$ \\
\hline $\begin{array}{l}10.45-12.00 \\
13.00-15.00\end{array}$ & Praktik & $\begin{array}{l}\text { Dadang Suhendar, SE., } \\
\text { M.Si } \\
\text { Dadang Suhardi, SE,MM }\end{array}$ \\
\hline $15.00-15.15$ & Penutupan acara & $\begin{array}{l}\text { PerwakilanTim PkM } \\
\text { Perwakilan Desa }\end{array}$ \\
\hline
\end{tabular}


Keberlanjutan Program, Setelah keseluruhan program selesai dilaksanakan, maka penting untuk direncanakan keberlanjutan program tersebut. Adapun keberlanjutan programdi lapangan setelah kegiatan PkM selesai dilaksanakan yaitu dengan memonitoring pembuatan laporan keuangan atau pembukuan sederhana mitra. Berdasarkan kegiatan pengabdian pada masyarakat yang dilaksanakan, adapun hasil dan luaran dari pemaparan materi yaitu :

1. Pada tahap awal dilakukan wawancara dan observasi kepada peserta mengenai pemahaman tentang dagang dan jasa serta fungsinya. Hasilnya menunjukan bahwa $70 \%$ mengetahui mengenai pentingnya pencatatan laporan keuangan.

2. Pada saat pemaparan materi disampaikan bahwa pembuatan laporan keuangan atau pembukuan memiliki manfaat untuk UKM.

3. Setelah materi disampaikan, peserta antusias menyampaikan berbagai pertanyaan.

4. Mayoritas pertanyaan fokus pada bagaimana membuat laporan keuangan yang baik dan benar serta sederhana dan mudah dipahami. Selain itu, beberapa peserta sharing mengenai pengalaman kegiatan usahanya terkait laporan keuangan yang dimiliki dan solusi dari permasalahan yang pernah dialami.

5. Pada wawancara dan observasi akhir, menunjukan perubahan dan peningkatan yaitu $85 \%$ peserta mengetahui dan memahami bahwa UKM merasakan manfaat dari pembuatan laporan keuangan atau pembukuan yang rapi dan jelas.

\section{SIMPULAN}

Berdasarkan kegiatan yang telah dilaksanakan oleh Tim di Desa Cibingbin Kecamatan Cibingbin Kabupaten Kuningan disimpulkan bahwa

1. Sosialisasi pengenalan UKM dan pembuatan laporan keuangan atau pembukuan yang sederhana untuk UKM telah memenuhi luaran yang ditargetkan yaitu terjadi peningkatan pemahaman mengenai pembuatan laporan keuangan atau pembukuan sederhana sehingga setelah sosialisasi diberikan maka peserta dapat menjelaskan tujuan dari pembuatan laporan keuangan atau pembukuan dalam kegiatan usaha.

2. Kegiatan tutorial yang dilakukan membuat UKM lebih memahami bagaimana membuat laporan keuangan yang sederhana terlihat baik dan jelas.

\section{SARAN}

Adapun saran yang dapat disampaiak untuk peningkatan kegiatan selanjutnya adalah menambah waktu untuk praktek dalam pembuatan laporan keuangan, UKM berencana untuk memperbaiki sistem pembuatan laporan keuangan atau pembukuan dalam usahanya.

\section{UCAPAN TERIMA KASIH}

Penulis ucapkan terima kasih kepada Rektor Universitas Kuningan, Pemerintah Desa Cibinuang atas segala dukungan yang telah diberikan sehingga terselenggaranya kegiatan pengabdian ini. Kegiatan pengabdian ini dibiayai Universitas Kuningan Berdasarkan Surat Persetujuan Rektor No. 81.39/SPK/LPPM.PM-UNIKU/KNG/2018 Tanggal 8 Juni 2018. 


\section{DAFTAR PUSTAKA}

Arsyad, Lincolin. 2008. Pengantar perencanaan dan pembangunan ekonomi daerah. BPFE Yogyakarta.

Hapsari, Andari, Hasanah. 2017. Model Pembukuan Sederhana Bagi Usaha Mikro Di Kecamatan Kramatwatu Kabupaten Serang. Jurnal Akuntansi. Vol 4 No. 2 Juli 2017

Ikatan Akutansi Indonesia ,2013, Standar Akuntansi Keuangan 2012, IAI Jakarta

Nitisastro, W. K. T. A. 2009. Penggunaan Business Technology Dalam Penyediaan Laporan Keuangan Perusahaan Dan Dampak Terhadap Perkembangan Usaha Studi Pada Usaha Mikro Kecil dan Menengah di Salatiga. Tesis tidak dipublikasikan. Program Pascasarjana UKSW Salatiga.

Purwanti. 2017. Analisis Pengetahuan Laporan Keuangan Pada Umkm Industri Konveksi Di Salatiga. Among Makarti Vol.10 No.20, Desember 2017

Rachmawan Budiarto,dkk,2015,Pengembangan UMKM, Gadjah Mada University Press

Rizky R,Sylvia V, 2012,Kualitas Laporan Keuangan UMKM Serta Prospek Implementasi SAK ETAP,Jurnal Akuntansi dan Keuangan Indonesia Vo.9,No1, Juni 2012

Setia Mulyawan,2015, Manajemen Keuangan, Pustaka Setia Bandung

Yoyo Sunaryo N. 2015. Perekonomian Indonesia. Uniku Press. Kuningan

Yoyo Sunaryo N .2014. Pemberdayaan UMKM dalam Koperasi. Edukati Press.

Kuningan 